\title{
Creme de Menthe Flavor
}

National Cancer Institute

\section{Source}

National Cancer Institute. Creme de Menthe Flavor. NCI Thesaurus. Code C73384.

A characteristic of a medicinal product, specifying that its most predominant agreeable savor detected by the unified sensation of taste and olfactory receptors resembles creme de menthe. 